\title{
8 Industrial zones in Burma and Burmese labour in Thailand
}

\section{Guy Lubeigt}

The military government's concerns with the industrialisation of Burma can be observed through the example of the development of satellite towns around Rangoon before the events of 1988 (Lubeigt 1989) and after them (Lubeigt 1993, 1994, 1995). The population surplus of downtown Rangoon and the squatters living around the pagodas and monastery compounds, who provided scores of demonstrators during the anti-socialist revolt, were expelled and forcibly resettled into the new townships created ex nibilo in far away paddy fields. ${ }^{1}$ Potentially explosive crowds of Central Rangoon were dispersed to South and North Dagon, Shwepyitha and Hlaingthaya by a junta keen to get rid of these trouble-makers. Small private industries causing a nuisance in residential quarters subsequently were also resettled in special areas, which became ipso facto 'industrial zones'. Meanwhile, bigger enterprises, mostly textile joint ventures established with foreign capital under the 'market-oriented economy' - successor of the failed socialist economy-were set up in Mingaladon Township on the eastern side of the main Rangoon-Pegu (Bago) road. 
Map 8.1 Industrial zones in Burma

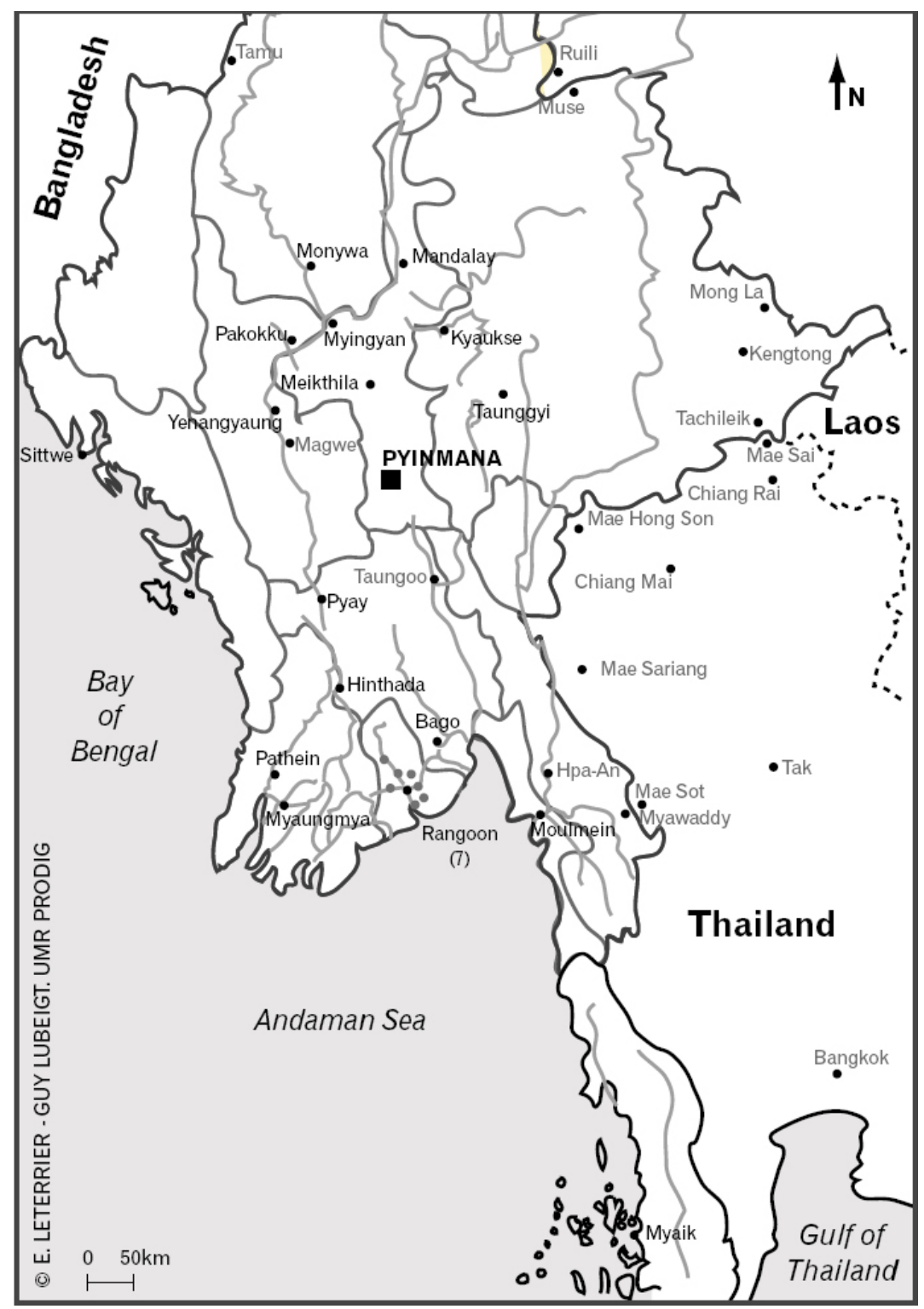


The location of these factories was not chosen at random, as Mingaladon is the main cantonment of the capital. Military families could provide an excellent and obedient workforce for these enterprises. Meanwhile, the construction of factories since the beginning of the 1990s had been quite limited and insufficient to provide many job opportunities for the civilian population. Therefore, with a growing population in search of a living, the gap between unemployment and job opportunities increased dramatically. The newly designed industrial zones were intended to bridge this gap.

In 1995, the military government set up the Myanmar Industrial Development Committee to encourage the development of the industrial sector. Thus the creation of industrial zones on the territory of the union could also be presented as a government goodwill gesture to provide job opportunities to its unemployed citizens. Since 2003, the Burmese authorities claimed to have organised nearly 43,000 private industries scattered throughout the whole country (Ministry of Information 2006). All private factories (93 per cent of the industrial sector in 2005), however, are not set up within the industrial zones delimitated by the authorities. Of the 82,000 industries officially

Table 8.1 Development of the private sector in 2006

\begin{tabular}{lrrr}
\hline Subject & $\mathbf{1 9 8 8}$ & 2005 & Progress \\
Private industries & 26,872 & 42,707 & 15,835 \\
Private industrialists & 31,200 & 40,000 & 8,800 \\
Business in industrial zones & - & 8,463 & 8,463 \\
Cottage industries & - & 8,500 & 8,500 \\
$\begin{array}{l}\text { Number of industrial exhibitions } \\
\text { Number of seminars on development } \\
\text { of the industrial sector }\end{array}$ & - & 5 & 5 \\
\hline
\end{tabular}

Source: Ministry of Information, 2006. Sustainable Development in the Sectors of Border Areas, Communication, Industry, Mining and Energy, Ministry of Information, Yangon:37. 
existing in the country, only 8,463 are believed to be located within the prescribed industrial zones (Ministry of Information 2006:32). ${ }^{2}$ Moreover, most of these enterprises are small in scale; many could be classified as cottage industries or family businesses. Therefore, with the exception of the garment sector, they do not generate many working opportunities for the unemployed. When US sanctions were imposed against Burma in mid 2003, government and foreign-owned factories had to close temporarily. As a result, the US State Department estimated in 2004 that of 350,000 workers in the garment sector, 40,000 to 60,000 (especially women) had been laid off (Table 8.1). ${ }^{3}$

A new concept: economic and trade zones on the borders

Initially, 18 industrial zones were established officially by the Myanmar authorities. Five more were added to the original list, the latest in 2006 (see Table 8.2). The 23 industrial zones are generally close to the main urban agglomerations (Ministry of Information 2006:35). The last, Thilawa-Kyauktan, is situated along the eastern bank of the Rangoon River, south of the former capital. In the near future, we can guess that another zone to accommodate the small and medium-sized nonpolluting private industries will be set up in Pyinmana, close to the new capital, Naypyitaw, where sugar cane and wood-processing industries have long been established. Other recent decisions include the setting up of industrial zones in Hpa-An (the capital of Karen State, where there is a large cement factory), Moulmein-Mawlamyine (the capital of Mon State, connected with Yangon and Mandalay since February 2005 , thanks to the railway bridge crossing the estuary of the Salween River) and Myawaddy, ${ }^{4}$ announced in October 2005.

The creation of these three zones, however, reflects a new concept: the sharing of the profits derived from specific economic and industrial zones between Burma and Thailand. The proposed zones are not only industrial, they are conceived as trading centres. This concept represents the implementation of the Economic Cooperation Strategy (ECS) agreed on in November 2003 at Pagan. The participants in this program are Burma, Cambodia, Laos and Thailand, but China was also present 
at the meeting. ${ }^{5}$ Vietnam joined in 2004 and the second summit of the group took place in Bangkok in November 2005. Encouraged by the success of its cooperation with Thailand, Burma is considering the creation of other economic and industrial zones on its borders with Bangladesh, India (Tamu-Moreh), China (Muse-Shweli) and Thailand (Tachilek-Mae Sai, Mae Hong Son and Kawthaung-Ranong).

The ECS provides for cooperation in five strategic areas covering agriculture, industry, trade and investment, transport, and tourism and human resources development. According to press reports of the Pagan meeting, 'the five-country economic cooperation is aimed at fully harness[ing] their huge economic potential to promote spontaneous and sustainable economic development by transforming the border areas of these countries into zones of durable peace and stability as well as economic growth'. ' Obviously, the border zones are of prime importance for the partners, especially Burma and Thailand, as they share a $1,800 \mathrm{~km}$-long border. ${ }^{10}$

Since the Union of Burma's independence, the governmentwhether civilian or military-has had difficulties controlling its eastern borders due to the presence of dozens of rebel movements hiding in the deep forests. Communists, republicans, nationalists and bandits carved their petty kingdoms in these mountainous, remote parts of the country. Each group controlled one or several passages giving access to Thailand. In exchange for their protection, merchants were paying some taxes to rebels (Shan, Lahu, Pa-O, Kayah, Karen, Mon). For decades, this revenue provided the opportunity to the rebels to finance their guerrillas acting against the central government. Thai smugglers, who were dealing with all the rebels, were also taking their share from these lucrative rebellions. After 1988, with the help of China, the junta revamped and expanded several-fold the size of the Tatmadaw (the military, now said to number about 350-400,000 men). ${ }^{11}$ Consequently, within a few years, most of the strongholds of the Shan and Karen rebels were retaken by the junta, which was nearly in full control of its border with Thailand. Thai smugglers, now converted into legitimate businessmen and investors, can deal openly with the 


\section{Table 8.2 Industrial zones in Burma, 2006}

\section{Yangon Division}

West Yangon: Hlaingthaya (453 hectares)

Northwest Yangon: Shwepyitha

Northeast Yangon: Shwepaukkan

East Yangon (Mingaladon-Pyinmabin)

Southeast Yangon: Dagon Myothit

Hmawby-Myaungdaka

$40 \mathrm{~km}$ north of Rangoon, 405 hectares

Thanlyin (Syriam)-Kyauktan-Thilawa port ${ }^{6}$

\section{Central Burma}

Mandalay south

Monywa

Kyaukse

Myingyan

Pakkoku

Meikthila

Yenangyaung-Chauk

Shan State

Taunggyi (capital of Shan State)

Arakan State

Sittwe (capital of Rakhine State) ${ }^{7}$

Irrawaddy Delta

Pyay

Hinthada

Myaungmya

Pathein

Pegu/Bago

Burma-Thailand border zone and Tenasserim Coast

Moulmein/Mawlamyine $\left(400,000\right.$ rais $\left.^{8}\right)$

Mergui/Myeik/Myaik

\section{Products}

Textiles, food processing

Steel mill, heavy industry production, plastic factory

Railway repairs; machinery equipment, diesel enginesusing imported Chinese technology - to produce small, 18-horsepower singlepiston engines; soft drink food processing, soap factories

Mechanics, gear boxes, textiles

Quarries, cement plant, brick factory, bicycle factory, shoes Textiles

Cigarettes, textiles, mechanics

Fisheries processing 
local Myanmar authorities provided they have the proper political and economic connections. Thus transactions within the economic and trade border zone between partners who have known each other for a long time are greatly facilitated.

Meanwhile, since 2004, Burma and Thailand have developed promising bilateral cooperation in planning the creation of the first three special economic and industrial zones in Hpa-An, Mawlamyine and Myawaddy. Both countries are expecting to benefit from the establishment of these industrial zones - economically and socially. Map 8.2 shows that these areas are situated not only in the frontier space, or close to it, but on the main lines of communications connecting India, Bangladesh, China, Burma and Thailand. Moreover, projected road extensions from the border zone of Myawaddy-Mae Sod and Tak in Thailand will offer direct access towards Vietnam (Danang) and the South China Sea.

Thai investors are interested in engagement in the three combined zones and, under Thai-Myanmar cooperation, Thai factories are planning to move into the delimited areas. Participants are already engaged in cooperation, especially in the domain of energy, with the construction of the Hogyit Dam on the Salween River, in which China is also a financial partner. Construction was set to start in January 2007. As the dam is only $60 \mathrm{~km}$ from the Thai border, factories are assured of access to a cheaper and permanent source of energy. ${ }^{12}$

For the Burmese side, economic and industrial zones have a triple advantage: they provide jobs to national workers; the industrial sector gets access to new technologies; and the taxes collected from the factories and traders replenish the public treasury. For the Thai side, there is also a triple advantage: factories located or relocated within the Burmese industrial zones enjoy profitable conditions (land lease for at least 75 years, profit taxes will be relaxed for re-investment with the profit earned annually); easy access to new markets (Burma, India, China) by road or by sea through the harbours of Mawlamyine or Rangoon; and especially the possibility of employing a low-paid, skilled and obedient 
Map 8.2 Industrial zones along the Thailand-Burma border

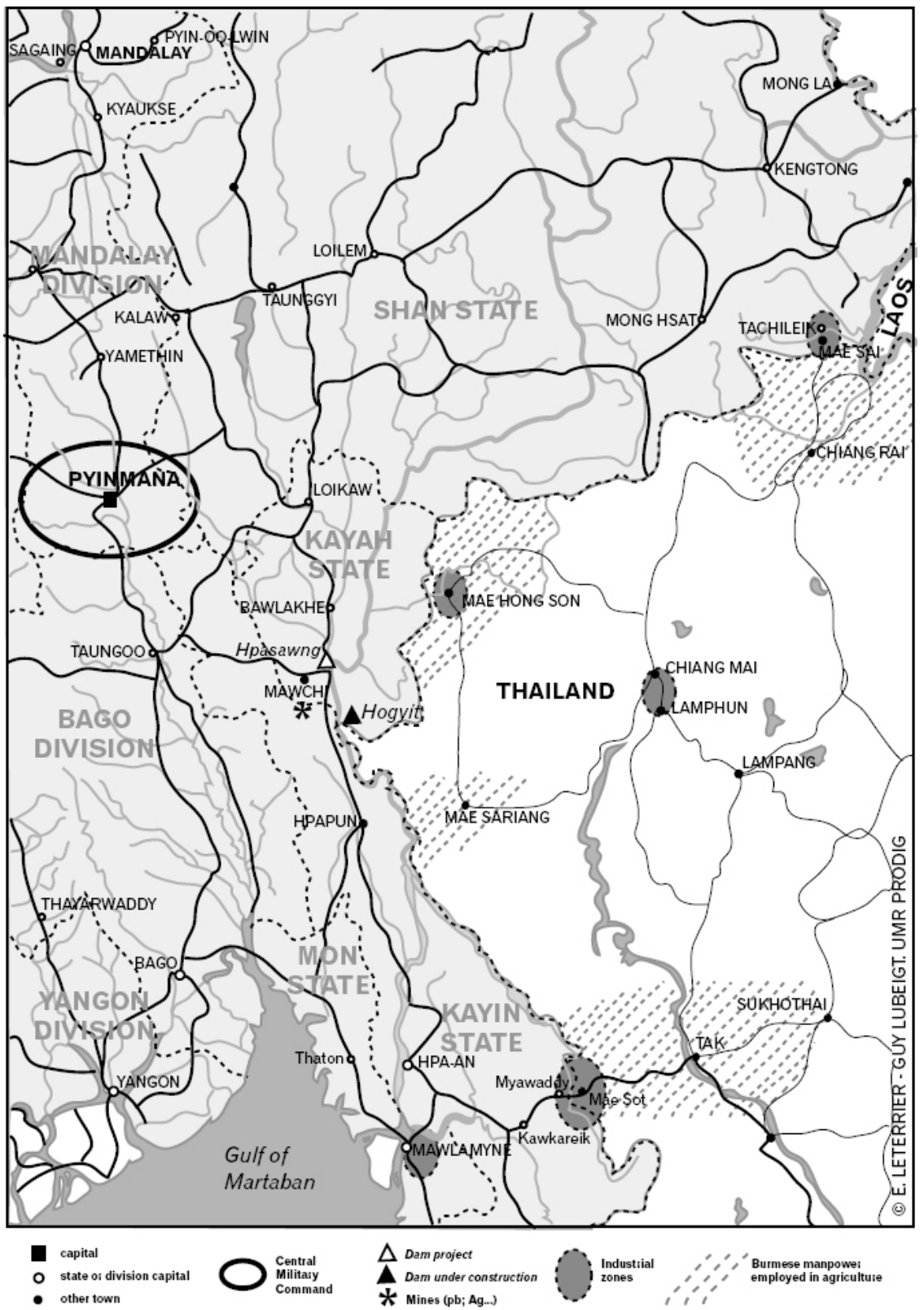


workforce. In such a win-win situation, the prospects for development of the economic and trade zones look rather bright, at least for the two governments.

For the time being, these three special zones are still in the making as negotiations between the two partners are not finalised. The questions of taxation and repatriation of the profits are not settled and potential factories are not yet in the position to create many jobs. Consequently, Burmese manpower, which cannot be employed at home, is still crossing the border in huge numbers, often paying soldiers guarding the checkpoints along the access roads to Thailand. ${ }^{13}$

\section{Unemployed workforce migrates to Thailand}

According to the Myanmar National Committee for Women's Affairs, using official statistics prepared by the government, the unemployment rate was 4.08 per cent in 1999 in a population of 49 million. ${ }^{14}$ In 2001, it appeared that 4.1 per cent of the nearly 52 million inhabitants were still unemployed (Ministry of Labour 2003:8). Given the increase of the population between 2000 and 2005 (more than five million people), it appears that the employment situation not only did not improve, it was further aggravated. Other sources are no more optimistic and estimate a rise in the unemployment rate to 5.6 per cent in 2005 (CIA 2005:10). Meanwhile, anonymous local sources claim that the real rate of unemployment could be more than 20 per cent, and still rising, if we consider the number of people looking for work. The discrepancy between these sources could be explained by the fact that the authorities do not record, or pay much attention to, the unemployed who have already left Burma to find a job elsewhere. In any case, unemployment appears to be a permanent feature of the potential Burmese workforce (Table 8.3).

Official estimates from the Labour Department show that the rate of unemployment was decreasing from 4.10 per cent in 1997 to 4.01 per cent in 2002 (Ministry of Labour 2003:8), contrary to all observations. The estimated rate of participation in the workforce was then nearly 64 per cent (Table 8.3). 
Table 8.3 Labour force and unemployment rate, 1996-2001

\begin{tabular}{lccccccc}
\hline Indicator & & $1996-97$ & $1997-98$ & $1998-99$ & $1999-2000$ & $2000-01$ & 2001-02 \\
Total labour force & $\mathrm{M}$ & 13.57 & 13.92 & 14.28 & 14.65 & 15.02 & 15.41 \\
& $\mathrm{~F}$ & 8.38 & 8.60 & 8.82 & 9.05 & 9.28 & 9.52 \\
& $\mathrm{~T}$ & 21.95 & 22.52 & 23.10 & 23.70 & 24.30 & 24.93 \\
& & & & & & & \\
Labour force & $\mathrm{M}$ & 78.57 & 79.09 & 78.63 & 79.19 & 79.68 & 80.26 \\
Participation rate & $\mathrm{F}$ & 47.18 & 47.64 & 46.67 & 47.01 & 47.32 & 47.65 \\
& $\mathrm{~T}$ & 62.66 & 63.17 & 62.35 & 62.78 & 63.18 & 63.63 \\
& & & & & & & \\
Unemployment rate & $\mathrm{M}$ & 3.68 & 3.66 & 3.64 & 3.62 & 3.60 & 3.57 \\
& $\mathrm{~F}$ & 4.77 & 4.77 & 4.76 & 4.75 & 4.74 & 4.73 \\
& $\mathrm{~T}$ & 4.10 & 4.08 & 4.07 & 4.05 & 4.03 & 4.01 \\
\hline
\end{tabular}

Source: Myanmar Labour Force Survey, Department of Labour (based on estimations), 2000.

If we apply that percentage in 2005, when the estimated total labour force was about 27 million workers, or half of the population, we obtain an estimation of 17.28 million workers participating effectively in the labour force. When compared with the estimated number of Burmese workers in Thailand in 2005 (more than two million), we discover that the Burmese workers in Thailand represent more than 11 per cent of the total Burmese workforce. ${ }^{15}$

For more than two decades, unemployed Burmese have developed informal strategies to find ways to meet their needs and feed their families. Many have illegally quit Burma and joined the foreign workforce employed in neighbouring countries. Especially attractive to Burmese workers are India, Malaysia and, in particular, Thailand. Since the beginning of the 1990s, an unprecedented flood of Burmese workers migrated to Thailand in search of job opportunities. Most 
of them headed towards two regions: the mountainous border space of Myawaddy-Mae Sot and, further to the south, the Bangkok area, especially the zone of Mahachai-Samut Prakan. Two other zones are known to have an important concentration of Burmese migrant workers: in the north, the border space of Tachilek-Mae Sai and, to the south, the area of Kawthaung-Ranong.

Table 8.4 Illegal migrant labour from Burma in Thailand, 1991-2004

\begin{tabular}{rrrrrrr}
\hline & $\begin{array}{c}\text { Arrested } \\
\text { migrant } \\
\text { workers from } \\
\text { Burma }\end{array}$ & $\begin{array}{c}\text { Arrested } \\
\text { migrant } \\
\text { workers in } \\
\text { Thailand }\end{array}$ & $\begin{array}{c}\text { Illegal } \\
\text { migrant } \\
\text { workers from } \\
\text { Burma }\end{array}$ & $\begin{array}{c}\text { Migrant } \\
\text { workers in } \\
\text { Thailand }\end{array}$ & $\begin{array}{c}\text { Legal } \\
\text { Migrant } \\
\text { workers in } \\
\text { Thailand }\end{array}$ & $\begin{array}{c}\text { Illegal } \\
\text { migrant } \\
\text { workers in } \\
\text { Thailand }\end{array}$ \\
1991 & 8,397 & 4,093 & 10,000 & & n.a. \\
1992 & 7,426 & 500,601 & n.a. & & n.a. \\
1993 & n.a. & 400,426 & n.a. & & n.a. \\
1994 & n.a. & 283,500 & 283,500 & & 520,000 \\
1995 & n.a. & 500,000 & 300,000 & & 590,000 \\
1996 & 7,664 & 500,134 & 500,000 & & 717,689 \\
1997 & 20,000 & 600,000 & 600,000 & & 900,000 \\
1998 & 290,000 & 350,000 & $1,000,000$ & & \\
1999 & 64,739 & $330,000^{\circ}$ & $600,000^{\circ}$ & & & \\
2000 & 130,000 & $330,000^{\circ}$ & $1,500,000$ & & & \\
2001 & & & & 568,000 & & \\
2004 & & & & $1,200,000$ & $850,000,000$ & \\
\hline
\end{tabular}

e estimate

Note: From one year to another registered workers can become illegal if they do not renew their registration with the Thai authorities. Many choose to do so.

Sources: Migrations from Burma. Report 2000. Federation of Trade Unions, 2002. 1991-93 Bangkok Post 13 May 1994, 28 July 1996; 1994 Bangkok Post, 22 January 1995; 1995 The Nation, January 1995; 1996 The Nation, July 1996 / Bangkok Post, 28 July 1996; 1997 The Nation, 28 April 1997/ Bangkok Post, 11 July 1998; 1998 Bangkok Post, 20 May 1998, 15 July 1999; 1999 Bangkok Post, 6 Nov 1999, 2000 Bangkok Post, 21 June 2000 / The Nation, 18 August 2000; 2001 Ministry of Labour of Thailand, 2001, 2004 Ministry of Labour and Social Welfare, Thailand. 
The number of Burmese immigrants working in Thailand was estimated at between 1.5 and two million in $2000 .{ }^{16}$ As many of them have been living illegally in Thailand for years, there is no reason to believe that their numbers would have decreased since then. On the contrary, border crossings have increased and the number of Burmese workers in Thailand, whether legal or illegal, can be safely estimated to be more than two million. It should be noted that estimations made in 2000 remain the same in 2006. Thus, it would be a surprise if the number of Burmese workers involved in the Thai apparatus of production remained the same when all information collected shows that workers rarely go back to Burma where they have no employment prospects.

Burmese women, previously estimated to represent only 20 per cent of migrant workers, are now entering Thailand in greater numbers in search of job opportunities. In Bangkok, they are in great demand in the services sector. A study conducted in 2005 by a team of researchers from Mahidol University in Bangkok revealed that about 100,000 Burmese women had taken up jobs as maids. ${ }^{17}$ Moreover, the number of Burmese sex workers in Thailand is said to be more than 20,000. In 2000, the Federation of Trade Unions Burma estimated that more than 80,000 women and children had been sold into Thailand's sex trade since 1990 . Here, too, movements have accelerated and cases of trafficking of Burmese women-sold as wives to Chinese farmers_- have begun to surface. The 155,416 refugees (mostly ethnic Karen) in 11 camps along the Thai-Myanmar border, who are not supposed to work (some do), are generally excluded from estimations (Table 8.4) (Macan-Markar 2006).

A mass migration movement of such magnitude can be described only as an exodus of the Burmese workforce. The reasons inciting so many Burmese citizens to find their way to Thailand are well known and have been described at length by the media and non-governmental organisations (NGOs). ${ }^{18}$

Burmese workers in Thailand: registered and illegal

Unemployed Burmese travel mainly to the zones where large numbers and cheap labour are needed. Depending on locations, their number 
was estimated at different periods: in Mae Sot, 100,000, of whom 50 per cent were illegal, in 2006; ${ }^{19}$ in Tak, 71,000 in 2001, ${ }^{20} 200,000$ in 2004; in Chiang Rai, Chiang Mai, Bangkok and Samut Sakhorn, 100,000 in 2001; in Samut Prakan and Ranong, 43,700 in 2001, ${ }^{21}$ 100,000 in $2004 ;^{22}$ in Takuapa, $10,000 .^{23}$

Realising the scope of Burmese immigration taking place in Thailand since the end of the 1990s, the government of Prime Minister Thaksin Shinawatra signed a memorandum of agreement with the Myanmar junta in June 2003 to deport 400 Burmese nationals a month directly into a holding centre operated by the Myanmar military intelligence organisation of General Khin Nyunt. ${ }^{24}$ Other immigrants, who were initially under the protection of the United Nations High Commissioner for Refugees (UNHCR), had to go underground to escape deportation. By the end of 2003, the Shinawatra government decided to abandon Thailand's long-standing humanitarian stance towards Burmese refugees. On 1 January 2004, the Thai authorities pressured the UNHCR to suspend its screening of new asylum-seekers from Burma. In the next months, all refugees settled in urban areas were moved and confined in camps along the border. The number of registered Burmese workers who had received temporary (one year) legal status fell from 500,000 in 2001 to 110,000 in $2003 .{ }^{25}$

By July 2004, the authorities reinforced their national campaign of registration of foreign workers. Attracted by an amnesty offer, 1.3 million illegal workers from Burma, Laos and Cambodia were recorded with the Thai Labour Ministry, with Burmese numbering 850,000. The administrative mechanism of registration was supposed to cope with the influx of migrant workers. Each of them had to pay 3,800 baht for a package including a medical check up, health insurance, work permit and relevant legal status. The registration was valid for one year so those who failed to re-register would become illegal immigrants again. If caught, they faced a jail sentence of up to three years and a 60,000-baht fine. Officially, no worker without a work permit would be allowed to remain in Thailand.

The registration system did not, however, put an end to the issue. Only 814,000 workers (64 per cent) were eventually issued proper work 
permits. Therefore, the legal foreign workers appeared to be composed of about 600,000 Burmese, 100,000 Laotians and 100,000 Cambodians. Added to that number were 93,000 migrant children less than 15 years old, among whom 80,000 were receiving no education. Most of them, illegally employed on agricultural works, could be considered victims of human trafficking. ${ }^{26}$ Meanwhile, many migrant workers have no money when they arrive and their prospective employers are unwilling to pay the registration fee on their behalf, or to lend money to them. Moreover, the local immigration and police officials were not excessively cooperative with the scheme because the legalisation of the Burmese workers-easy prey as they were-was cutting into the lucrative possibilities for extortion. Living in constant fear of deportation, many bona fide migrant workers obviously escaped underground. ${ }^{27}$ Undocumented, they unfortunately routinely experience abuse and ill treatment from employers, authorities and local communities and are threatened with arrest and deportation.

\section{Burmese workers in Thailand}

Myawaddy-Mae Sot: an industrial zone on the border

The Mae Sot area is of special interest because, in contrast with other well-known cities such as Bangkok and Phuket, this zone is situated close to the Burma-Thailand border, just opposite the old Burmese town of Myawaddy. The Burmese workers in search of employment can therefore cross the border easily to find jobs on the other side. They have only to cross a bridge over the Mae Nam Moi River (a tributary of the Salween River) to reach Thailand. The other reason why Burmese jobless choose this border crossing is that it is easily (and safely) accessible by road. Most of the workers are either urbanites or from populations living traditionally in the border area. Those coming from the hinterland have often been living in Rangoon for a few years. Thai factories (mostly textiles) relying on Burmese labour are established in and around the town and up to Tak. They can be compared with the system of the machiladoras on the border between Mexico and the United States. 


\section{Map 8.3 Asian highways across Burma}

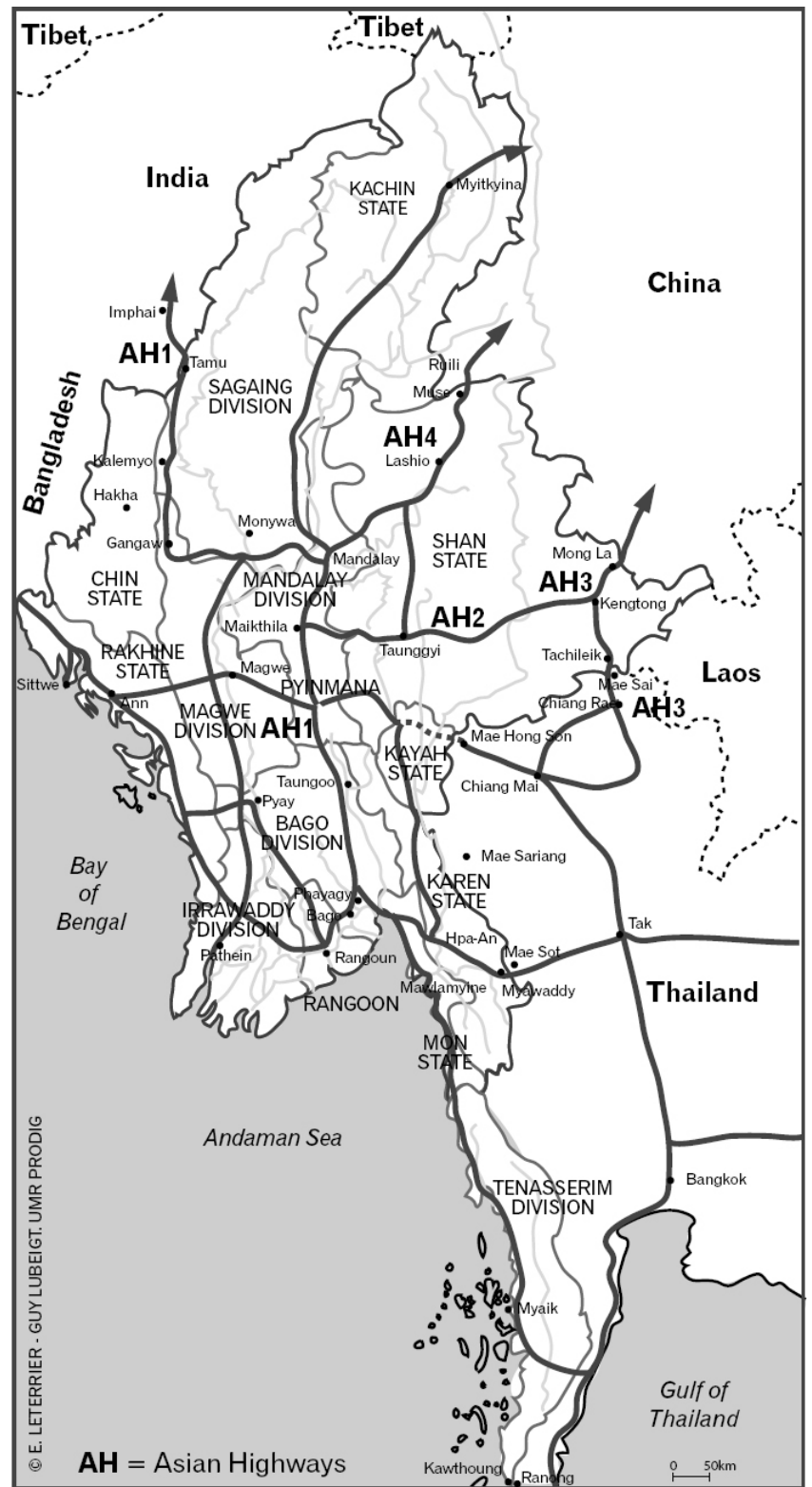


That road is part of the Asian Highway One (or, some say, 'the old Paris-Saigon road'), which, from India and the border town of Tamu, enters Thailand at Mae Sot, runs down to Bangkok and then across to Ho Chi Minh City through Phnom Penh. Now Asian Highway One also links China with its branches, $\mathrm{AH} 2, \mathrm{AH} 3$ and $\mathrm{AH} 4$ crossing in Mongla, Muse and Kachin State. Soon it will also be connected to Bangladesh. Asian Highway One is part of the East-West economic corridor that will link the transportation networks of central Vietnam and Burma through Laos and Thailand as part of the Greater Mekong Subregion development program.

The Myawaddy-Mae Sot border area has, however, a major inconvenience for the jobless: it is still partly a war zone, with fighting between the Tatmadaw and the leftover Karen and Shan rebel forces (KNU and Shan State Army South). Therefore, some migrants proceed south on the Mawlamyine-Tavoy road (which is also sometimes cut by the operations of small groups of Karen and Mon rebels) to reach Mergui. From there, they can cross the Tenasserim Range in the valley following the Tenasserim River up to the Maungdaung Pass, which has been used since prehistoric times to reach the Gulf of Siam. Most migrants, however, prefer to go to Kawthaung from where they can cross easily to the border town of Ranong. From Ranong, job-seekers can be recruited illegally by many Thai agents who dispatch them (after payment) either further south (to Phuket) or towards Samut PrakarnBangkok, where there is a big demand for Burmese manpower.

The Myawaddy-Mae Sot zone, long an attractive area for ordinary Burmese workers, is now also attractive for the Burmese and Thai authorities - so much so that the border area, already chosen for development as a common Special Economic and Industrial Zone between the two countries, is going to become the second largest such zone in Burma. ${ }^{28}$ This pilot project of cooperation, much inspired by the Chinese economic zones, is founded on the existence of available manpower, which could be employed in the factories planned for Burma, on the other side of the border. More economic and trade border zones will follow, including in Tamu (the border town with 
India) and Maungdaw (the border town with Bangladesh). As Burma has 13 main border-trade points with its four neighbouring countries, the prospects are large.

Joint exploitation of human resources

Expanding its cooperation with Thailand, Burma has recently agreed to lease fallow lands to Thailand in the border areas (Tachilek, Mae Hong Son, Mae Sariang, Hpa-An, Ye) ${ }^{29}$ Under the system of contract farming, seven million hectares have been reserved for cultivation. Burma agreed to plant crops (sugar cane, oil palm, cassava and rubber) that will be exported and processed in the economic and industrial zones or in Thailand. This system is conducted under the Irrawaddy-Chao Phraya-Mekong Economic Cooperation Strategy. The practice is applied to agricultural crops that are labour intensive and is aimed at import substitution. The system is intended to generate jobs in neighbouring countries and will support investment expansion between partners. Further, it is hoped to effectively solve illegal border crossings by migrant workers, reduce health and social problems originating from illegal labour and patch up the differences in development levels between Thailand and its neighbours, especially Burma. Basically, Thai goods will become cheaper because the raw materials and the labour will be cheaper in the other countries. ${ }^{30}$ Whatever the reason given, Burmese and Thai authorities have jointly decided to exploit fully the human resources available in Burma. The Burmese side wants to get a share of the profits generated by the exploitation of its workforce in Thailand, ${ }^{31}$ while the Thai side will gladly take advantage of the cheap manpower offered by the Burmese junta.

Burmese workers (because they are usually illegal) are passive, easy to handle and easy to bully; no strikes and no demands for the amelioration of working conditions are likely from them. They are often not provided with housing, running water or medical care, if they are not registered, and their working hours are extended at will (often nine to 16 hours a day, poorly paid, or with no pay at all). Any rebellion is punished immediately by expelling the recalcitrant workers to the 
other side of the border; or by threatening or beating them. It can go as far as assassinations.

Through a network of seasoned smugglers and traffickers well connected with the Burmese army on one side, and with police and immigration officials on both sides, Burmese labourers are brought to their destinations: the factories in Thailand. Thai and Burmese brokers, police and immigration officers connected with factories owners and human traffickers organise the recruitment-and sometimes the sale_of workers.

Migrant workers: the new slaves of the globalised world

The influx of migrant workers is so huge that the employment possibilities have spilled over into the Mae Sot economic zone towards Tak. Burmese workers are in great demand everywhere. They are employed not only in factories, but in agriculture (orchards), construction, as housemaids and, of course, for prostitution. Among many advantages, the Burmese worker can be easily dismissed or replaced, because, when a position is vacant, several new workers (often waiting on the other side of the border) are ready to come in and take a job for any salary at all. Above all, Burmese workers are cheap. Desperate in Burma, they accept between 40 and 60 baht a day, which is only one-third of what would be paid to Thai workers. ${ }^{32}$ Compared with salaries paid in Burma, even after the government salary increases of 1 May 2006 (up to US\$30 a month for a high-level government civil servant previously receiving US\$5-6 a month), this is still quite a boon for the jobless (Table 8.5).

Burmese migrant manpower in Thailand is exploited at will by Thai employers. Surveys suggest that these factories are often owned by ethnic Chinese (from Thailand, Taiwan, Hong Kong, Malaysia or Singapore). For these entrepreneurs, the only goal is profit by any means. And, for them, Burmese workers-as foreigners with no rights to stay or work in Thailand - are no more than expendable spare parts. Like many migrant workers throughout the world, the Burmese workforce can therefore be included in a new category of workers: the slaves of the globalised world. ${ }^{33}$ 
Table 8.5 Types of jobs and salaries paid to Burmese workers in Thailand

No. Types of jobs

\begin{tabular}{lll} 
& \multicolumn{1}{c}{$\begin{array}{c}\text { Daily } \\
\text { baht }\end{array}$} \\
1 & Agriculture & \\
2 & Cold storage & \\
3 & Construction & $100-180$ \\
4 & Coastal fishing & \\
5 & Fishery (deep-sea) & \\
6 & Food shops & \\
7 & Gas stations & \\
8 & Gem cutting & \\
9 & Gem mining & \\
10 & Golf courses & \\
11 & Industry & $150-180$ \\
12 & Housekeeping* & \\
13 & Logging & $80-150$ \\
14 & Saw mills & $80-160$ \\
15 & Services & $90-160$ \\
16 & Restaurants* & \\
17 & Rice mills & \\
18 & Rock grinding & $80-160$ \\
19 & Slaughter houses & \\
20 & Paper mill & $90-160$
\end{tabular}

Wages/Salaries

US\$

Monthly

US\$

2,500

71.42

2,500

71.42

2.29-4.57

2,000

57.14

2,500

71.42

2,000

57.14

1,500

3,500

2,000

57.14

2,000

57.14

$2.85-4.57$

1,000

28.57

$2.28-4.28$

2.28-4.57

2.57-4.57

2,000

57.14

2,500

71.42

$2.28-4.57$

2,000

57.14

* with a place to stay. Maids work nine to 16 hours a day.

Note: The situation remains the same in 2006.

Source: Federation of Trade Unions Burma, 2002. Migrant Workers from Burma.

Amazingly, at the same time, when Sino-Thai employers exploit their Burmese, Laotian and Cambodian 'slave workers' in Thailand, ${ }^{34}$ Thai workers employed abroad (in Taiwan) have to revolt against the working conditions imposed on them by their Taiwanese employers in Taipei. These conditions, described as inhumane by the Thai workers themselves, led in August 2005 to riots against the Chinese employer. Thai press reports of the events, curiously, did not draw a parallel between the situation of the Thai workers in Taiwan and that of the Burmese workers in Thailand. ${ }^{35}$ 
In Singapore, foreign workers are mostly legal and protected by law when working in factories. Individual employers, however, seldom respect the law and also exploit their Burmese maids. ${ }^{36}$ The Singaporean press mentions and sometimes denounces the actions of Chinese employers (especially abuses against maids) when such cases happen to be brought to court. But this occurs only rarely in Thailand, and then it is principally because Thai government representatives in foreign countries immediately take up the abuses of the employers in order to help or protect their fellow citizens, whether the latter have migrated legally or not. ${ }^{37}$ In Burma, the government-controlled press never mentions the plight of the expatriate Burmese workers in Thailand, mainly because they often left Burma illegally. ${ }^{38}$ When Burmese workers have proper documentation, the Burmese authorities gladly accept their monthly remittances in Burma and charge a fee to renew their passport in Thailand every two years (10 per cent of their salary), but they do not bother to intervene on their behalf. If a worker is in conflict with his or her employer, the reaction of the Burmese representation is always the same: the Burmese worker involved is immediately sent back to Burma, and the matter is then considered closed.

In the border zones, where no Burmese consulate exists, the workers are abandoned to their fate and receive no protection from their authorities whatsoever. Whether in Thailand, Malaysia or Singapore, local laws are not made for the benefit of migrant workers. On the contrary, the tendency of the authorities is to use the migrant workers as pawns for bargaining.

\section{A Thai economy fed by cheap manpower}

For more than a decade, the Thai Immigration Police have regularly announced new measures to curb immigration-legal and illegal — from neighbouring countries. Thai policy fluctuates between crack-downs and registration, arrests and bans, or forced repatriation and expulsion, but to little avail. Burmese job-seekers (as well as Laotian and Khmer) can sneak into Thailand. While the Thai government is at pains to control its porous borders, ${ }^{39}$ the foreign workforce is secretly encouraged 
to come in to work for employers willing to take advantage of the cheap cost of their labour.

Meanwhile, since 2006, Thai entrepreneurs and investors have realised that a serious problem is looming for the Thai economy. There will soon be severe labour shortages in seven key industries (petrochemical, food, automotive, tourism, textiles, software and logistics) because Thai schools do not produce the right personnel to serve the expansion of the economy. The Education Ministry recently announced that, within three to five years, there will be a shortfall of almost 585,000 workers in Thailand. ${ }^{40}$ Moreover, some managers already complain that it is difficult to employ Thai workers coming directly from farms to the factories. These workers have to follow a special formation to enter fully the line of production. In such cases, the local authorities (and the government) are always prompt to react in favour of the investors and cater to their manpower needs. Unfortunately, the education sector has been neglected by the government since 2001 and promised reforms have not taken place. ${ }^{41}$

After a decade of tough policy designed to return illegal immigrants to Burma, ${ }^{42}$ a new policy was set up on 1 October 2006 to allow in a special quota of skilled workers requested by seafood-processing factories and fishing trawlers - areas in which Thais do not want to work. Given that the evaluation of the need was clear, the solution chosen by the Thai authorities was rapid. While the government was monthly expelling 10,000 Burmese migrants from Thailand in 2003, under the program of 'informal deportation', it will now facilitate the official entry of skilled Burmese workers into Thailand to take up the positions available in its factories. A shift in Thai policy towards migrant workers began in May 2005 with authorisation given to foreign workers residing in border areas to come to work in Thailand providing they returned to their homes every evening. The hinterland factories relying on the cheap Burmese labour are, however, hungry for manpower. Entry permits for Thailand recently delivered to 10,000 skilled Burmese workers are only the beginning of a new process; more will follow to cater to the needs of the Thai economy. 
In continental Southeast Asia, workers fuelling the economy are recruited preferably from neighbouring countries with a manpower surplus. ${ }^{43}$ According to Chidchai Vanasatidya, ${ }^{44}$ 'there will be no illegal immigrants living or working in Thailand by the end of next year.' A new mechanism to control the foreign workers will then be fully operational. The Immigration Police will lead 10 other government agencies responsible for national security and civilian intelligence services in stamping out illegal entry, unlawful employment and human trafficking. Some 100 million baht will be spent on creating a database containing details of all foreigners entering, leaving, living and working in Thailand. The system will certainly work with all the bona fide travellers presenting their passports at the different ports of entry into Thailand, but its efficiency is doubtful when confronted with the illegal Burmese, Laotian and Cambodian migrants willing to enter the country to find work, or with the illegal Chinese determined to use Thailand as a departure base for economic migration to Western countries.

\section{Conclusion}

Massive migration of Burmese workers into Thailand affects both countries. On one hand, it depletes the availability of skilled workers in Burma, which is a clear loss for a developing country, while on the other hand, Thailand benefits from such a reservoir of cheap manpower. Burma receives the monthly remittances of its expatriate workers, but Thai entrepreneurs capitalise on the value added to their export-oriented productions by the work of the Burmese migrants.

Each country is aware of the size of the phenomenon and its impact on their economy, but each reacts differently. The Myanmar junta chooses to ignore the huge emigration taking place, because it reduces the potential of social, if not political, demands building up within society. The Thai government plays down the boost given to its economy by the widespread use of cheap Burmese workers by its industries, and prefers to play up the supposed or real social disorders said to be brought by Burmese immigrants: increase of diseases such as malaria, tuberculosis 
and HIV; the drain on hospital resources to care for sick Burmese; ${ }^{45}$ the expansion of prostitution; and murders and thefts. The dual attitude of the Thai authorities is politically useful to hide their own social and health shortcomings from their own population. The contribution of migrants to the Thai economy is still unrecognised officially, although a 'new vision' towards migrants is beginning to appear in government circles, probably out of necessity and to be in accordance with the Economic Cooperation Strategy illustrated by the launch of the first economic and industrial zone in Myawaddy-Mae Sot. For their part, Burmese authorities, until now ignoring the plight of their expatriate workers, recently realised the potential political benefits of monitoring such a huge workforce in Thailand.

\section{Notes}

1 Inhabitants of these townships need one to two hours of travel on dilapidated buses to reach the downtown.

2 Other statistics record more than 100,000 'industries' employing more than two million workers in the whole of Burma.

3 In 2002, Burmese exports to the United States, mostly garments, were worth US\$356 million. Garments were then the second largest export. By September 2005, the Burmese garment industry revived with the imposition of US and EU quotas on Chinese imports. American and European retailers immediately boosted their orders from other low-priced suppliers. Since then, private sources explain that big factories (often South Korean-owned) have quietly reopened in Burma and export their production to South Korea, where labels are stitched on before being re-exported to the United States and Latin America as South Korean products.

4 Covering 396, 275 and 384 hectares respectively. The Myawaddy zone is a pilot project that will be the prolongation, in Burmese territory, of the Mae Sot industrial zone.

5 This project is also known as the Ayeyawaddy (Irrawaddy)-Chao PhrayaMekong Economic Cooperation Strategy (ACMECS). Three participants (Burma, Laos and Vietnam) share a common border with China, but all share the waters of the Mekong River, which are controlled increasingly by China.

6 Established in May 2006 as a Special Industrial Zone with 100 per cent foreign investment, the Thilawa port zone will be the first export-concentration zone in 
which all formalities for export of the zone's products will be handled. Most, if not all, of the investments for the construction have been provided by China. Therefore the law governing the zone includes restrictions on investment by domestic national entrepreneurs unless it is done with joint investment from foreign counterparts.

7 Development project with a special industrial zone based on natural gas from offshore.

8 Many plots located between Hpa-An (capital of Karen State) and Moulmein (capital of Mon State) have been allotted to be parts of an economic and industrial estate to be built within the framework of Burma-Thailand cooperation. The zone will be connected with the industrial zone of Mae Sot. The rai is the Thai unit for measurement of area ( $1 \mathrm{rai}=1600$ square metres).

9 Xinhuanet reporting from Yangon, 30 October 2005.

10 Burma and China also share 2,185 kilometres of common border along the Yunnan Province.

11 For an assessment of the size of the army, see also Mary Callahan's chapter in this volume.

12 The Hogyit Dam is also located almost equidistant between Naypyitaw and the industrial zones of Hpa-An, Mawlamyine and Mae Sot. It is the first of the five gigantic hydroelectric plants planned on the lower course of the Salween River by Burma and the Electricity General Authority of Thailand. The dams will have a combined capacity of 11,800 megawatts (MW), with the giant Ta-Sang having 7,110MW. The dams are said by Thailand to be necessary to ensure adequate energy supplies in the region. The actual capacity of Burma is $1,335 \mathrm{MW}$, up from $707 \mathrm{MW}$ in 1988 .

13 The author observed such a check-point in March 2005 on the road from Thanbyuzayat to Ye on the Tenasserim coast.

14 Myanmar National Committee for Women's Affairs 2001:28 (from the Handbook on Human Resources Development Indicators, 2000). This organisation, presided over by wives of generals, is fully controlled by the military regime.

15 In 2002, the number of Burmese workers in Thailand was estimated to be between 7.9 and 10.5 per cent of the total Burmese workforce. See Lubeigt 2002:1.

16 General Sarit Sarutanon, Joint Chief of the National Police, Bangkok Post, 21 June 2000. Cited in Caouette and Pack, 2002. The estimation is reproduced in Federation of Trade Unions Burma 2002. The Federation is an exiled organisation connected with the democracy movement. 
17 Bangkok Post, 29 0ctober 2005.

18 See the well-documented field reports of Battistella, G. and Asis, M.M.B., 1999; Caouette et al. 2000; Huguet 2005; Horton 2006; Human Rights Watch 2004; and BHPWT August 2006.

19 Democratic Voice of Burma, 5 July 2006.

20 Arnold, D., 2004

21 Arnold, D., 2004

22 According to Naing 2004, Ranong itself had 40 karaoke bars and brothels; and 150 Burmese prostitutes operated their trade in the town. Given the number of Burmese workers living in the area, this survey remains doubtful.

23 Unitarian Universalist Service Community, January 2005.

24 Shinawatra abandoned Thailand's traditional policy in order to please the junta, with which he had several business deals. For Burmese intelligence, the aim was mainly to get information on the resistance movements developing in Thailand in the wake of the attack on Nobel Prize-winner Aung San Suu Kyi (on 30 May 2003) by a mob of Union for Solidarity and Development Association (USDA) members, sponsored by the junta.

25 Bangkok Post, 15 July 2004.

26 The Nation, 24 August 2005.

27 It is difficult to differentiate between asylum-seekers, refugees, migrant workers, refugees having to work to sustain their families and political refugees or those exiled. Most of the migrants fit into several categories at the same time. Their common identity is that they have all been driven out of Burma by the policies of the military regime.

28 The 105th Mile Border Trade Zone, established on the Burma-China border of Yunnan Province in April 2006, is the first zone in terms of importance. The manpower in the zone is, as in Mongla, actually Chinese.

29 Possibly taken from 'relocated' Shan and Karen villages; 600,000 to one million members of ethnic minorities are said to have been internally displaced by the Burmese junta.

30 Bangkok Post, 1 December 2005.

31 Another, political benefit seems to emerge for the Burmese authorities, who want their illegal workers to come back to Burma to register. After verification of their ethnic nationality, travel documents will be issued to certified workers to return to Thailand. This new regulation results from a memorandum of understanding signed between Senior General Than Shwe and Prime Minister Shinawatra during the last unpublicised visit of the latter to Burma in August 2006. Only belatedly aware of the agreement, the Thai press denounced the move as an attempt to implant more pro-junta supporters in Thailand, 
especially those related to the USDA, in order to spy on the activities of the Burmese community living there. See Chongkittavorn 2006:9.

32 The daily official minimum wage is set by the Thai government. In May 2005, it was 175 baht in Bangkok; 173 baht in Phuket; 149 baht in Chiang Mai; 147 baht in Ranong; and 139 baht in Mae Sot.

33 The situation is better for the Laotians as they speak Thai, while the Cambodians often understand the Issan dialect of northeastern Thailand.

34 The idea of slavery, now being discussed without provoking horror or widespread condemnation, seems to be accepted. See Bangkok Post 2005.

35 In mid December 2006, as Thai industries needed more labour, the press campaigned for the protection of the rights of Burmese workers. See Chongkittavorn 2006:9.

36 The number of Burmese maids employed in Singapore (currently paid S\$300-450 monthly) could be as high as 50,000. One of them claims that 80 per cent of the Chinese bosses are 'very bad with their employees'. Maids have one day off twice a month. Another complained that after her arrival she had no day off for four years (verbal communication, 20 July 2006).

37 Mainly to avoid being criticised, the Thai press is always prompt to defend the rights of the Thai citizens unfairly treated.

38 Official documents are costly (US\$3,000), difficult to obtain (taking three to six months) and there is no guarantee of finding a legitimate job. Only seamen, who are in great demand as they speak English, are officially recruited by private agencies in Burma. They leave officially and benefit from the 'protection' of the government because they send back handsome (by Burmese standards) monthly remittances. The amount sent back by the workers to Burma is said to be $\$ 6$ billion ( $\$ 1.5$ billion for the 150,000 Thai overseas workers). The Nation, 24 August 2005.

39 To control its more than 5,000 kilometres of border, Thailand deploys 3,800 immigration officers. The Nation, 4 August 2006.

40 The Nation, 4 August 2006. Details from the previous registration show that 177,226 Thai employers wanted to hire 1,087,834 migrant workers. At the same time, 13,487 migrant workers entering Thailand were arrested and 7,354 of them are now being prosecuted. The Nation, 7 September 2006.

41 There have been six ministers of education in six years.

42 One can wonder whether such a policy was designed to effectively send back the illegal workers to their country of origin, or to keep pressure on the foreign job-seekers willing to accept wages amounting to one-third of the salaries that should legally be paid to Thai workers (see note 39). 
43 According to AFP (22 June 2005), Malaysia is one of Asia's largest importers of labour. Foreign workers, legal and illegal, number about 2.6 million of its workforce of 10.5 million.

44 Then deputy Prime Minister in the Shinawatra caretaker government. $\mathrm{He}$ was holding the portfolio of Home Minister jointly until he was ousted by the coup of 19 September 2006. The Nation, 4 August 2006.

45 According to the Public Health Ministry Inspector-General, Dr Kitisak Klabdee, the Burmese patients' unpaid medical bills at hospitals in Tak were expected to exceed 70 million baht in 2005, because hundreds of thousands of them living near the border had no medical insurance. Bangkok Post, 29 June 2005.

\section{References}

Agence France Presse, 2005. 'Malaysia to ban abusive employers, consider letting refugees work: reports', Agence France Presse, 22 June.

Arnold, D., 2004. 'The situation of Burmese migrant workers in Mae Sot, Thailand', Working Paper Series, No. 71, September, Southeast Asia Research Centre, City University of Hong Kong, Hong Kong.

Backpack Health Worker Team, 2006. Chronic Emergency: health and human rights in Eastern Burma, September, Backpack Health Worker Team, Bangkok.

Bangkok Post, 2005. Burmese maids get treated like "slaves" in Thailand", Bangkok Post, 29 October 2005.

Bangkok Post, 2005. 'Myanmar agrees to cultivate seven million hectares under contract farming with Thailand', Bangkok Post, 1 December.

Battistella, G. and Asis, M.M.B., 1999. The Crisis and Migration in Asia, Scalabrini Migration Center, Quezon City.

— undocumented migration, International Symposium on Migration, Bangkok, 21-23 April 1999, International Organisation for Migration and Scalabrini Migration Centre, Bangkok and Manila.

Callahan, M.P., 2003. Making Enemies. War and state building in Burma, Cornell University Press, Ithaca.

Caouette, T. Kritaya, A. and Pyne, H. H., 2000. Sexuality, Reproductive Health and Violence: experiences of migrants from Burma in Thailand, 
Institute for Population and Social Research, Mahidol University, Bangkok.

Caouette, T.M. and Pack, M.E., 2002. 'Pushing past definitions: migration from Burma to Thailand', Refugees International and Open Society Institute, Washington DC.

Central Intelligence Agency (CIA), 2005. The World Factbook, Burma, Central Intelligence Agency. Available from http://www.cia.gov/cia/ publications/factbook/geos/bm.html

Chongkittavorn, K., 2006. 'Thailand's cynical ploy on Burmese migrant workers', The Nation, 11 December 2006:9.

Chulalongkorn University, 2003. 'Reviewing Policies and Creating Policies to Protect Migrant Workers', conference organised by the Institute of Asian Studies, Bangkok.

Evans, G, Hutton, C.M, Kuah, K.E., 2000. Where China Meets Southeast Asia, White Lotus, Bangkok.

Federation of Trade Unions Burma, 2002. Migrant Workers from Burma. Horton, G., 2005. Dying Alive: a legal assessment of human rights violations in Burma, Report to the Netherlands Ministry of Development Cooperation, Images Asia, Chaingmai. Available from: http://www. ibiblio.org/obl/docs3/Horton-2005.pdf

Huguet, G.W. and Sureeporn, P., 2005. International migration in Thailand, report to the International Organisation for Migration, 23 August 2005, Bangkok. Available from http://www.old.iom.int/documents/ publication/international_migration_thailand_23_aug_05.pdf

Human Rights Watch, 2004. Human Rights Watch World Report, Human Rights Watch, New York.

Kasem, S., 2005. 'Burmese to leave B70m in unpaid bills', The Nation, 29 June.

Lubeigt, G., 1989. 'Aspects du développement de la zone péri-urbaine de Rangoun (Birmanie)' [Notes on the Development of the peripheral urban zone of Rangoon], in La Péri-urbanisation dans les pays tropicaux, Bordeaux, CNRS-CEGET, Espaces Tropicaux, No.1:327-84.

__, 1993. 'Les dimensions socio-politiques et culturelles de la périurbanisation en Birmanie' [The social-politics and cultural dimensions of the peripheral urbanisation in Burma], in Métropolisation et périurbanisation, Cahiers du CREPIF, No.42 (March):165-6. 
_, 1994. 'Birmanie: une nouvelle péri-urbanisation' [Burma: a new peripheral urbanisation in Burma], in Penser la ville de demain-Qu'est-ce qui institue la ville?, L'Harmattan, Paris:203-14.

—_ 1995. 'Données stratégiques d'un aménagement urbain en Birmanie: de Rangoon à Yangon' [Strategic Facts of an Urban Development in Burma: From Rangoon to Yangon], in Cités d'Asie, Les Cahiers de la Recherche Architecturale, Nos 35-6, Editions Parenthèses/diff. PUF (March):141-51.

_ 1998 . 'Réflexions sur l'espace frontalier birmano-siamois et ses enjeux traditionnels (XIIIème-XIX ème siècles)' [Reflections on Burma-Siam Frontier and its Traditional Stakes (thirteenth -nineteenth Centuries], in Guerre et Paix en Asie du Sud-Est, Collection 'Recherches Asiatiques', Sophia University (Tokyo) et L'Harmattan, Paris:9-38.

__ 1999. 'Ancient transpeninsular trade roads and rivalries over the Tenasserim coasts', in Trade and Navigation in Southeast Asia (fourteenth-nineteenth centuries), Collection 'Recherches Asiatiques', Sophia University (Tokyo) et L'Harmattan, Paris:47-76.

_ 2002. Esclaves du monde moderne: les travailleurs migrants birmans en Thaillande, Communication to the conference of Reseau Asie, CNRS, Paris, September.

Macan-Markar, M., 2006. 'Ethnic groups pin hopes on visiting UN official', Inter Press Service, 17 May.

Maneepong, C., 2006. 'Regional policy thinking and industrial development in Thai border towns', Labour and Management in Development Journal, 6(4), The Australian National University and University of Tasmania, Asia Pacific Press, Canberra. Available from http://labour-management. anu.edu.au/volumes/prt/volsix/6-4-Maneepong.pdf

Maung Aung Myoe, 2002. Neither Friend Nor Foe: Myanmar's relations with Thailand since 1988, a view from Yangon, Institute of Defence and Strategic Studies, Singapore.

Ministry of Information, 2006. Sustainable Development in the Sectors of Border Areas, Communication, Industry, Mining and Energy, Ministry of Information, Yangon.

Ministry of Labour, 2000. Myanmar Labour Force Survey, Department of Labour, Yangon. 
Ministry of Labour, 2003. Handbook on Human Resources Development Indicators, 2002, UNFPA and Department of Labour, Yangon.

Myanmar National Committee of Women's Affairs, 2001. Gender Statistics in Myanmar, Myanmar National Committee of Women's Affairs, Yangon.

Naing, W., 2004. 'The trafficking trap persists in border towns', Inter Press Service, 18 December 2004.

Rajah, A., 1994. Burma: protracted social conflict and displacement, Paper presented at the International Conference on Transnational Migration in the Asia Pacific Region: Problems and Prospects, Bangkok.

Santimatanedol, A., 2005. 'Migrant workers "exploited"—-study: Burmese maids get treated like "slaves"', Bangkok Post, 29 October.

Shakti, R.P., Supang, C. and Naing 1997. Reproductive Health Survey: migrant Burmese women in Ranong Fishing Community, Thailand, April, Institute of Asian Studies, Bangkok.

Stern, A. and Crissman, L.W., 1998. Maps of International Borders Between Mainland Southeast Asian Countries and Background Information Concerning Population Movements at these Borders, February, Asian Research Center for Migration, Institute of Asian Studies, Chulalongkorn University, Bangkok.

Taylor, R.H., Tin Maung Maung Than and Kyaw Yin Hlaing (eds), 2005. Myanmar: beyond politics to societal imperatives, ISEAS Publications, Singapore.

The Coalition to Stop the Use of Child Soldiers, .Child Soldiers: country briefs. Available from http://www.child-soldiers.org

The Nation 2006. 'Illegal immigration should end next year', The Nation, 4 August.

The Nation, 2006. 'Workers registered Oct 1', The Nation, 7 September. Tin Maung Maung Than, 1999. Mimicking a developmental state: Myanmar's industrialization effort (1948-62), The Myanmar Two Millennia Conference, 15-17 December, Yangon.

United Nations Interagency Project on Human Trafficking, . UN Interagency Project on Human Trafficking in the Greater Mekong Sub-Region, United Nations Interagency Project. Available from http://www.no-trafficking. org/Publication/publications.html

Wilson, T. (ed.), 2006. Myanmar's Long Road to National Reconciliation, ISEAS Publications and Asia Pacific Press, Singapore and Canberra. 